\title{
Interferon- $\gamma$ and tumour necrosis factor induce expression of major histocompatibility complex antigen on rat retinal astrocytes
}

\author{
Ahmed M Abu El-Asrar, Davide Maimone, Peter H Morse, Chris Lascola, Anthony T Reder
}

\begin{abstract}
Cultured rat retinal astrocytes were tested by indirect immunofluorescence staining for their ability to express class I and II major histocompatibility complex (MHC) antigens under basal culture conditions and after three days of stimulation with two recombinant cytokines, rat interferon- $\gamma($ IFN- $\gamma)$ and human tumour necrosis factor $\alpha$ (TNF $\alpha)$. Under basal culture conditions low levels of class I antigens were detected on a small percentage of cells, but there was no visible class II. IFN- $\gamma$ and TNF $\alpha$ stimulation enhanced class I expression. TNF $\alpha$ had no effect on class II expression, whereas IFN- $\gamma$ induced the expression of class II in a dose dependent manner. These findings suggest that retinal astrocytes might play a part in immunological events occurring in the retina.
\end{abstract}

The retina, like the central nervous system, is considered immunologically privileged because of the presence of a blood-retina barrier and the lack of lymphatic drainage. Nevertheless, it can be the target of immune mediated reactions such as diabetic retinopathy, retinal vasculitis, ${ }^{\prime}$ experimental autoimmune uveoretinitis, ${ }^{2-4}$ viral infections such as herpes simplex, varicella zoster, cytomegalovirus, and toxoplasmic retinitis. Recent work has demonstrated that brain astrocytes are involved in immunological events occurring in the central nervous system..$^{5-8}$ The immune functions of retinal astrocytes, however, have not been studied. Some authors suggest that they are not essential for any retinal function. ${ }^{9}$

Major histocompatibility complex (MHC) antigens play an important part in the initiation of immune responses, and their expression on retinal astrocytes could trigger or facilitate immune functions in the retina. Class II MHC antigens, recognised by CD4 helper and CD4 cytotoxic $\mathrm{T}$ cells, are necessary for antigen presentation and for limited cytotoxic cell functions. Class I MHC antigens are recognised on target cells by CD8 cytotoxic cells, which constitute the majority of cytotoxic $\mathrm{T}$ cells in vivo. ${ }^{10-13}$

Cytokines, secreted by lymphocytes and macrophages, serve as soluble mediators of immune cell activity and can regulate their expression of MHC molecules. Among these cytokines, interferon- $\gamma(\text { IFN- } \gamma)^{51+16}$ and tumour necrosis factor $\alpha(T N F \alpha)^{17-20}$ induce class I and II MHC antigens on a variety of cell types in vitro.

In order to understand the pathogenesis of retinal immune-mediated diseases, it is neces- sary to identify factors that enhance $\mathrm{MHC}$ antigen expression on retinal cells. We examined the effect of the cytokines IFN- $\gamma$ and TNF $\alpha$ in inducing the expression of MHC antigens on cultured rat retinal astrocytes.

\section{Materials and Methods}

RECOMBINANT PROTEINS AND ANTIBODIES

Rat recombinant IFN- $\gamma$ was purchased from Amgen Biologicals (Thousand Oaks, CA, USA), and recombinant human $\mathrm{TNF} \alpha$ was obtained from Knoll Pharmaceuticals (Whippany, New Jersey, USA). Rabbit monoclonal antibody to human glial fibrillary acidic protein (GFAP) was obtained from Chemicon International (Temecula, CA, USA), and mouse monoclonal antibodies to rat class I and II MHC (polymorphic) antigens were purchased from Serotec (Oxford, UK). Secondary antibodies were fluorescein-conjugated goat anti-mouse IgG from Cappel Laboratories (Malvern, PA, USA), and fluorescein-conjugated goat anti-rabbit IgG from Tago (Burlingame, CA, USA).

\section{CULTURE CONDITIONS}

Retinas were dissected from the eyes of postnatal day 1 Holtzman rats under sterile conditions with the aid of a stereomicroscope, placed in culture medium, and mechanically dissociated by trituration through progressively smaller needles. A suspension of approximately $2 \times 10^{6}$ cells in $1.5 \mathrm{ml}$ of culture medium was added to each poly-L-lysine $(50 \mathrm{mg} / \mathrm{l})$-coated $35 \mathrm{~mm}$ Petri dish (Falcon). The culture medium was Dulbecco's modified Eagle's medium (DME) (Sigma Chemical Company, St Louis, MO, USA) supplemented with $10 \%$ heat inactivated calf serum, penicillin (20 units $/ \mathrm{ml}$ ), and streptomycin $(20 \mathrm{mg} / \mathrm{ml})$. Cultures were incubated at $37^{\circ} \mathrm{C}$ in a humidified atmosphere of $5 \%$ carbon dioxide$95 \%$ air. The growth medium was changed twice weekly. Three-week-old cultures were used throughout this study.

Astrocytes were identified by the presence of cytoplasmic glial fibrillary acidic protein, an intracellular antigen unique to astrocytes. ${ }^{21}$ The cells were fixed for $5 \mathrm{~min}$ in $5 \%$ acetic acid/ ethanol on ice. A rabbit monoclonal antibody to human GFAP (1:50) was incubated with retinal cells for $30 \mathrm{~min}$ on ice, followed by a $30 \mathrm{~min}$ incubation with fluorescein-conjugated goat anti-rabbit IgG $(1: 20)$. The cells were then mounted with $60 \%$ glycerol in trometamol (tris) buffered saline, and visualised by fluorescent microscopy. Astrocyte cultures were $>95 \%$ positive for GFAP (Fig 1). 
Figure 1 A GFAP+ retinal astrocyte. Cultures were $>95 \%$ GFAP+. (Indirect

immunofluorescence staining, $\times 800$.)

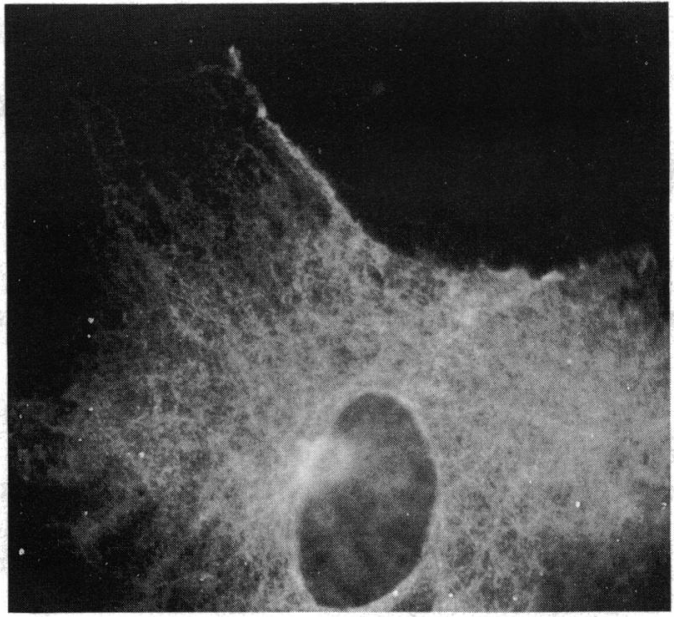

IFN- $\gamma$ AND TNF $\alpha$ TREATMENTS

Cultures were treated with IFN- $\gamma(2-200 \mathrm{U} / \mathrm{ml})$ or TNF $\alpha(50 \mu \mathrm{g} / \mathrm{l})$ for three days before they were stained. For control purposes parallel cultures were maintained in the culture medium alone.

INDIRECT IMMUNOFLUORESCENCE STAINING FOR CLASS I AND II MHC ANTIGENS

The cells were incubated for $20 \mathrm{~min}$ with $5 \%$ goat serum, followed by a $60 \mathrm{~min}$ incubation with monoclonal antibodies to rat class I $(1: 50)$ or class II (undiluted) determinants at $4^{\circ} \mathrm{C}$. The cells were then washed three times with phosphate buffered saline (PBS) containing $1 \%$ bovine serum albumin and $0.02 \%$ sodium azide, followed by a $30 \mathrm{~min}$ incubation with fluorescein conjugated goat anti-mouse IgG (1:20) on ice. After being washed three times the cells were fixed for $10 \mathrm{~min}$ in $4 \%$ paraformaldehyde, mounted in $60 \%$ glycerol in trometamol buffered saline, and examined by inverted fluorescent microscopy (Leitz) $\times 1000$. As controls some cultures were incubated with the washing solution in place of first antibody or with an irrelevant monoclonal antibody of the same isotype. Neither control displayed positive staining.

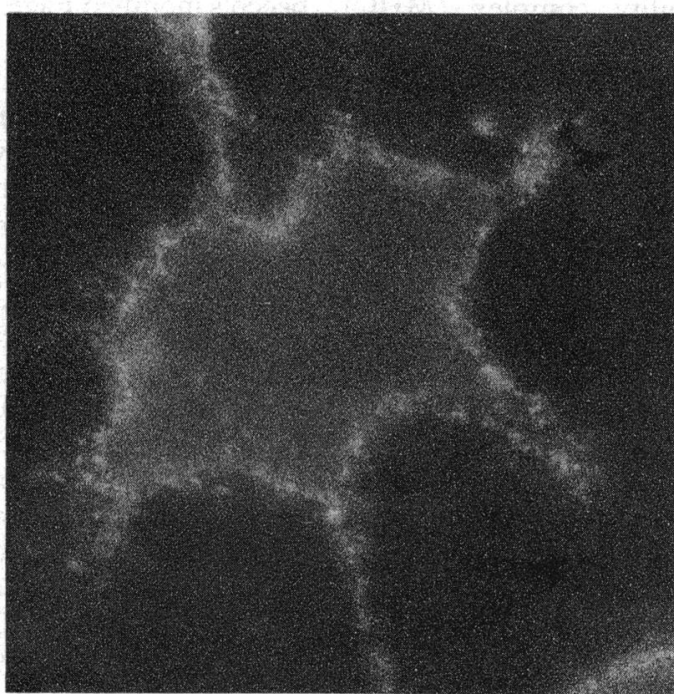

Figure 2 MHC class II surface antigen detection on a retinal astrocyte following treatment with $I N F-\gamma(10 \mathrm{U} / \mathrm{ml})$ (Indirect immunofluorescence staining, $\times 800$.)

\section{Results}

Untreated cultured rat retinal astrocytes expressed low levels of class I MHC antigens in a small percentage of cells $(<10 \%)$, whereas class II MHC antigens were not detected.

Recombinant IFN- $\gamma$ treatment enhanced class I expression. The percentage of cells expressing class I increased from a baseline of $<10$ to $>95 \%$. Following exposure to IFN- $\gamma$ at $2-200 \mathrm{U} / \mathrm{ml}$. IFN- $\gamma$ at 2 or $5 \mathrm{U} / \mathrm{ml}$ induced low levels of class II antigen synthesis by a few cells $(<10 \%)$. Maximum expression by most of the cells $(>95 \%)$ followed exposure to IFN- $\gamma$ at $10-200 \mathrm{U} / \mathrm{ml}$ (Fig 2).

Recombinant TNF $\alpha$ at $50 \mu \mathrm{g} / \mathrm{l}$ induced high levels of class I antigens on most of the cells $(>95 \%)$. On the other hand, TNF $\alpha$ had no stimulatory effect on class II antigen expression.

\section{Discussion}

These data show that in rat retinal astrocytes under basal culture conditions low levels of class I MHC antigens are expressed by a few cells, but class II antigens are not expressed. IFN- $\gamma$ enhances the expression of class I antigens and induces the expression of class II antigens. In addition, TNF $\alpha$ induces class I expression on the surface of retinal astrocytes, whereas class II expression is not affected by TNF $\alpha$ treatment.

Surface expression of MHC antigens is the molecular basis for antigen presentation. ${ }^{14}$ Class II antigens are found on cells involved in immune responses, including B cells, activated human and rat $T$ cells, and antigen presenting cells such as macrophages. The presence of class II antigens on these cells is associated with antigen recognition and presentation to $T$ cells and the initiation of specific $B$ and $T$ cell responses. ${ }^{22}{ }^{23}$ IFN- $\gamma$ from activated $T$ cells is a potent inducer of both class I and II antigens on cells; brain astrocytes treated with IFN $-\gamma$ also express class II antigens. ${ }^{5}$ Brain astrocytes, on expression of class II antigens, can function as antigen presenting cells and present antigens such as myelin basic protein to specifically sensitised $\mathrm{T}$ cells. ${ }^{6} \mathrm{By}$ analogy with the brain, IFN- $\gamma$-induced expression of class II MHC antigens on retinal astrocytes could allow these cells to act as antigen presenting cells and in turn play a part in immunological events occurring in the retina.

Several studies have demonstrated close contact between retinal astrocytes and retinal vascular tissue. ${ }^{2+26}$ Accordingly, active contact between the immune system and the retina may directly depend on astrocyte function and makes the astrocytes one of the first cells encountered by intruding $\mathrm{T}$ cells.

TNF $\alpha$ is produced by mononuclear phagocytes $^{27}$ and astrocytes ${ }^{28}$ in response to inflammatory stimuli. It increases expression of class I MHC antigens on brain astrocytes, ${ }^{29}{ }^{30}$ but it has no effect on induction of class II MHC molecules. $\mathrm{TNF} \alpha$, however, augments class II induction on brain astrocytes in conjunction with virus infection $^{31}$ or IFN- $\gamma .^{19}$ Class I MHC antigens are particularly important for $\mathrm{T}$ cell recognition of virus antigens expressed on the surface of infected cells. ${ }^{32}$ Brain astrocytes can be suscept- 
ible targets in vitro for class-I-specific cytotoxic T lymphocytes. ${ }^{33}$ Accordingly, class I enhancement on retinal astrocytes induced by IFN- $\gamma$ or TNF $\alpha$ may render these cells susceptible targets for class-I-restricted cytotoxic lymphocytes.

In conclusion, our data show that IFN- $\gamma$ and TNF $\alpha$ induce MHC antigens on rat retinal astrocytes in culture. These cytokines could be released by activated immune cells recruited to the retina in response to a viral infection or during immune mediated diseases that cause breakdown of the blood-retina barrier. Class I enhancement could render retinal astrocytes susceptible targets for class-I-restricted cytotoxic $\mathrm{T}$ lymphocytes. In addition, once astrocytes express class II, they may function as antigen presenting cells and induce further expansion of $\mathrm{T}$ lymphocyte clones within the retina.

This work was supported by the Peace Fellowship Programme for Egypt, sponsored by the Agency for International Development, Washington DC 20523.

1 Rahi AHS, Addison DJ. Autoimmunity and the outer retina. Trans Ophthalmol Soc UK 1983; 103: 428-37.

2 Fox GM, Kuwabara T, Wiggert B, et al. Experimental autoimmune uveoretinitis (EAU) induced by retinal interphotoreceptor retinoid-binding protein (IRBP): differences between EAU induced by IRBP and by S-antigen. Clin Immunol Immunopathol 1987; 43: 256-64.

3 Caspi RR, Roberge FG, Chan CC, et al. A new model of autoimmune disease. Experimental autoimmune uveoretinitis induced in mice with two different retinal antigens. f Immunol 1988; 140: 1490-5.

4 Schalken JJ, Winkens HJ, Van-Vugt AH, Bovee-Geurts PH, de-Grip WJ, Broekhuyse RM. Rhodopsin-induced experimental autoimmune uveoretinitis: dose-dependent clinicopathological features. Exp Eye Res 1988; 47: 135-45.

5 Wong GHW, Bartlett PF, Clark-Lewis I, Battye F, Schrader JW. Inducible expression of H-2 and Ia antigens on brain $\mathrm{JW}$. Inducible expression of $\mathrm{H}-2$
cells. Nature $1984 ; 310: 688-91$.

6 Fontana A, Fierz W, Wekerle H. Astrocytes present myelin basic protein to encephalitogenic T-cell lines. Nature 1984; 307: 273-6.

7 Massa PT, Dörries R, ter Meulen V. Viral particles induce Ia antigen expression on astrocytes. Nature $1986 ; 320$ : 543-6.

8 Takiguchi M, Frelinger JA. Induction of antigen presentation ability in purified cultures of astroglia by interferon- $\gamma . \mathcal{F ~ M o l}$ Cell Immunol 1986; 2: 269-280.

9 Stone J, Dreher Z. Relationship between astrocytes, ganglion cells and vasculature of the retina. $\mathcal{F}$ Comp Neurol 1987; 255: 35-49.

10 Swain SL. Significance of Lyt phenotypes: Lyt2 antibodies block activities of $\mathrm{T}$-cells that recognise class I major histocompatibility complex antigens regardless of their histocompatibility complex antigens regardless of
function. Proc Natl Acad Sci USA 1981; 78: 7101-5.

11 Krensky AM, Reiss CS, Mier JW. Long term human cytolytic T-cell lines allospecific for HLA-DR antigen are OKT4 ${ }^{+}$. Proc Natl Acad Sci USA 1982; 79: 2365-8.

12 Meurer SC, Schlossman SF, Reinherz EL. Clonal analysis of human cytotoxic lymphocytes: $\mathrm{T}^{+}$and $\mathrm{T} 8^{+}$effector $\mathrm{T}$-cells recognize products of different major histocompatibility complex regions. Proc Natl Acad Sci USA 1982; 79: 4395.
13 Allen PM. Antigen processing at the molecular level. Immunol Today 1987; 8: 270-3

14 Unanue E, Beller DI, Lu CY, Allen PM. Antigen presentation: comments on its regulation and mechanisms. F Immunol 1984 ; 132: $1-5$.

15 Abu El-Asrar AM, Van den Oord JJ, Billiau A, Desmet V, Emarah MH, Missotten L. Recombinant interferon-gamma
induces HLA-DR expression on human corneal and endothelial cells in vitro; a preliminary report. $\mathrm{Br} \mathcal{F}$ Ophthalmol 1984; 73: 587-90.

16 Sasaki A, Levison SW, Ting JPY. Comparison and quantitation of Ia antigen expression on cultured macroglia and ameboid microglia from Lewis rat cerebral cortex: analyses and implications. F Neuroimmunol 1989; 25: 63-74.

1 Collins T, Lapierre LA, Fierz W, Strominger JL, Pober JS. Recombinant human tumor necrosis factor increases mRNA levels and surface expression of HLA-A,B antigens in vascular endothelial cells and dermal fibroblasts in vitro. Proc Natl Acad Sci USA 1986; 83: 446-50.

18 Lavi E, Suzumura A, Murasko DM, Murray EM, Silberberg DH, Weiss SR. Tumor necrosis factor induces expression of MHC class I antigens on mouse astrocytes. $\mathcal{J}$ Neuroimmunol 1988; 18: 245-53.

19 Benveniste EN, Sparacio SM, Bethea JR. Tumor necrosis factor- $\alpha$ enhances interferon- $\gamma$-mediated class II antigen

20 Cannella B, Raine CS. Cytokines up-regulate Ia expression in organotypic cultures of central nervous system tissue. F Neuroimmunol 1989; 24: 239-48.

21 Bignami A, Eng LF, Dahi D, Uyeda CT. Localisation of the glial fibrillary acidic protein in astrocytes by immunofluorescence. Brain Res 1972; 43: 429-35.

22 Thoresby E, Berle E, Nousiainen H. HLA-D region molecules restrict proliferative T-cell responses to antigen. Immunol Rev 1982; 66: 39-56.

23 Unanue ER. The regulatory role of macrophages in antigenic stimulation. Part two: symbiotic relationship between lymphocytes and macrophages. Adv Immunol 1981; 31: lymphocy.

24 Drager UC, Edwards DL, Barnstable CJ. Antibodies against filamentous components in discrete cell types of the mouse retina. F Neurosci 1984; 4: 2025-42.

25 Schnitzer J, Karschin A. The shape and distribution of astrocytes in the retina of the adult rabbit. Cell Tissue Res 1986; 246: 91-102.

26 Schnitzer J. Retinal astrocytes: their restriction to vascularised parts of the mammalian retina. Neurosci Lett 1987; 78: 29-34.

27 Beutler B, Cerami A. Cachectin and tumor necrosis factor as two sides of the same biological coin. Nature 1986; 320: two sic-8.

28 Lieberman AP, Pitha PM, Shin HS, Shin ML. Production of tumor necrosis factor and other cytokines by astrocytes stimulated with lipopolysaccharide or a neurotropic virus. Proc Natl Acad Sci USA 1989; 86: 6348-52.

29 Mauerhoff T, Pujol-Borrell R, Mirakian R, Bottazzo GF. Differential expression and regulation of major histocompatibility complex (MHC) products in neural and glial cells of the human fetal brain. F Neuroimmunol 1988; 18:271-91.

30 Lavi E, Suzumura A, Murasko DM, Murray EM, Silberberg DH, Weiss SR. Tumor necrosis factor induces expression of MHC class I antigens on mouse astrocytes. $\mathcal{F}$ Neuroimmunol 1988; 18: 245-253.

31 Massa PT, Schmipl A, Wecker E, ter Meulen V. Tumor necrosis factor amplifies virus-mediated Ia induction on necrosis factor amplifies virus-mediated la induction

32 Zinkernagel RM, Doherty PC. MHC-restricted cytotoxic T-cells: studies on the biological role of polymorphic major T-cells: studies on the biological role of polymorphic major transplantation antigens determining T-cell restrictionspecificity, function

33 Skias DD, Kim DK, Reder AT, Antel JP, Laucki DW, Fitch FW. Susceptibility of astrocytes to class I MHC antigenspecific cytotoxicity. $\mathcal{F}$ Immunol 1987; 138: 3254-8. 